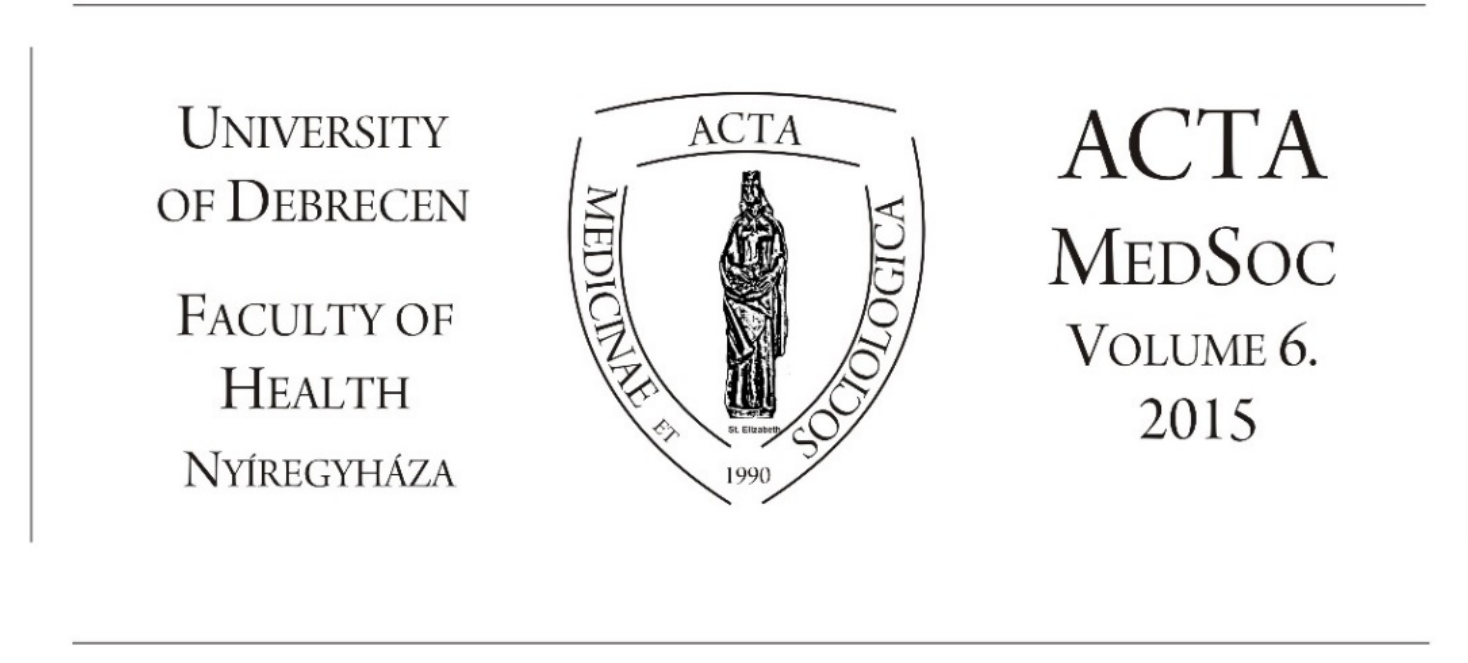

\title{
Szociális problémák és a segélyezési rendszer átalakulása a Nyíregyházi járás településein
}

\author{
Krizsai Anita - Tóthné Csatlós Ildikó
}

\begin{abstract}
The aim of this study to show the transformation of the social beneficial system and the way of it's financing. We will show the solutions of the different municipalities in the district of Nyíregyháza. The differences between the county center and the municipalities of the district of Nyíregyháza also will be shown, and we will put the focus especially the following things: support of the basic living, the role of the organized support system and the sort of benefits.
\end{abstract}

Keywords: Supportive systems, social problems, social benefits.

\section{Bevezetés}

A rászorult személyekről való gondoskodás hosszú idők óta a települések feladata közé tartozik, a formája alapján hol a gondozást (mai szóval a szolgáltatások biztosítását), hol a pénzügyi támogatást előnyben részesítve. A rendszerváltást követően elfogadott szociális törvény (a szociális igazgatásról és szociális ellátásokról szóló 1993. évi III. törvény, továbbiakban Szt.) majd időben később megjelent gyermekvédelmi törvény (a gyermekek védelméről és a gyámügyi igazgatásról szóló 1997. évi XXXI. törvény) megteremtette annak a lehetőségét, hogy a települési önkormányzatok segélyezési rendszerüket maguk alakítsák ki a törvény által meghatározott jogszabályi keretek között. A decentralizációs törekvések eredményeképpen kialakult segélyezési rendszer azonban számos problémát vetett fel, melyek végül centralizációs lépések megtételéhez vezettek. Elsőként egyes ellátások (időskorúak járadéka, aktív korúak támogatása, normatív 
ápolási díj) esetén normatív szabályozást vezettek be azzal, hogy a feladat- és hatásköröket a települési önkormányzatok jegyzőihez telepítették. Az így kialakított rendszerben a szociális igazgatási feladat- és hatáskörök megoszlottak a települési önkormányzatok képviselő-testülete, a települési önkormányzat polgármestere, illetve jegyzői között.

A szociális igazgatás területén újabb jelentős változtatásokra 2013-ban került sor. Új közigazgatási, területi egységként megjelent a járás. ${ }^{53} \mathrm{~A}$ járások kialakításával az önkormányzatoktól átkerültek az okmányirodai feladatok, a gyermekvédelmi és gyámügyek, valamint egyes szociális (időskorúak járadéka, egészségügyi szolgáltatásra való jogosultság, ápolási díj és közgyógyellátás egyes jogcíme), környezetvédelmi, természetvédelmi igazgatási ügyek. A hatáskörök szétválasztásánál kiemelt szempont volt, hogy a helyi szabályozáshoz kapcsolódó, mérlegelési jogkörbe tartozó ügyek, a helyi viszonyok ismeretét (pl. birtokvédelem) és a helyi azonnali reagálás szükségességét igénylő ügyek (pl. katasztrófavédelmi feladatok) lehetőleg maradjanak a települési jegyzőnél.

2015. március 1-től az Szt. hatályba lépő módosítása keret jellegü szabályok kialakításával ismét a helyi közösségekre bízza a segélyezés konkrét elveinek és szabályainak kialakítását települési támogatásként. Magyarország 2015. évi központi költségvetésének megalapozásáról szóló 2014. évi XCIX. törvény indokolása szerint a helyi közösségek rendelkeznek ugyanis leginkább azzal a tudással, amely alapján eldönthetik: ki jogosult támogatásra és ki nem. Az önkormányzatok szabadon dönthetnek a támogatások nagyságáról és formájáról.

Az új rendszer számos kérdést és dilemmát vet fel, melyeket részben a kialakuló gyakorlat válaszol meg, részben pedig a jogszabályi feltételek módosítását is eredményezheti. Jelen tanulmány arra vállalkozik, hogy felvázolja a Nyíregyházi járás településein a lakosság számára a segélyezés milyen formái érhetőek el, a kialakult rendszert milyen körülmények befolyásolják - azaz a települési önkormányzatok a segélyezési rendszer kialakításakor milyen mutatókat vesznek figyelembe -, a lakosság elégedettsége milyen mértékü, milyen eredményei mutathatók fel a járási hivatalok és a települési önkormányzatok közötti feladatmegosztásnak.

\footnotetext{
${ }^{53}$ A járások kialakítása a közigazgatás átfogó, a közjót szolgáló átalakításának, a Jó Állam kialakításának egyik eleme, amelyről 2011. őszén határozott a Kormány. A járás, mint az állam szervezetének legalacsonyabb szintü területi és szervezeti egységének a kialakítását a hatékonyabb, költségtakarékosabb és ügyfélközpontú területi közigazgatás megteremtése indokolta. A járások és járási hivatalok a fóvárosi és megyei kormányhivatalok szervezeti egységeiként kerültek felállításra 2013. január 1-jével. A járási kormányhivatalok legfontosabb feladata a megyei szintnél alacsonyabb szinten intézendő államigazgatási feladatok ellátása.
} 


\section{Az önkormányzatokat befolyásoló tényezők}

Strukturális változások, jogszabályok módosulása, foglalkoztatási problémák, a társadalmi konfliktusok megelőzésének, kezelésének fokozódó szükségessége, a lakosságmegtartás kihívásai, a humánszolgáltatások újraszervezésének új körülményei, bizonyos településméretek esetében (járás, kistérség) komplex szolgáltatások megszervezésének szükségessége - ebben a környezetben kell az önkormányzatoknak saját stratégiát kialakítani, és megtalálni a lehető legjobb megoldásokat a felmerülő problémák kezelésére, megoldására.

A segélyezés rendszerének alakításakor alapvetően az adott településen élő lakosság demográfiai, társadalmi, gazdasági jellemzői, foglalkoztatottsági mutatók a meghatározóak. ${ }^{54}$ Kisebb településen igaz lehet, hogy „mindenki ismer mindenkit", a nagyobb lélekszámú településeken azonban helyi és központi statisztikai adatokra, felmérésekre, előzetes tanulmányokra lehet alapozni. A lakossági szükségletek és igények ismeretén túl (vagy előtte) fontos a rendelkezésre álló pénzügyi lehetőségek, a financiális háttér megteremtése.

Az elöbbi e tanulmánykötet más fejezetében részletesen bemutatásra kerül, a tanulmányban a finanszírozás hátterét és a változások hatását vagy várható hatásait mutatjuk be röviden.

A pénzbeli és természetbeni ellátások biztosításának fedezetét 2015 előtt a központi költségvetésben biztosított állandó lakosok után járó támogatás és kötött felhasználású támogatás jelentette. A települési önkormányzatok az éves költségvetésük elkészítésekor betervezték az állami forrásokat, amelyek egyes támogatásoknak 80-90\%-os mértékü finanszírozását jelentette, melyet az ágazati jogszabály tartalmazott. ${ }^{55}$ Ezek a támogatások a munkanélküliek részére járó aktív korúak ellátása, az ápolási díj, a lakásfenntartási támogatás, az adósságcsökkentési támogatás és a közgyógyellátás. A méltányossági alapon járó juttatások, illetve az eseti támogatások fedezetét is biztosította az állami támogatás. A települési önkormányzatok egyéb önként vállalt feladataikat pedig saját forrásból fedezték.

2015-től az állami szabályozási hatáskörben nyújtott és az önkormányzat segélyezéssel kapcsolatos feladatok szétváltak. Az Szt. csak a járások hatáskörébe tartozó ellátásokra vonatkozó szabályokat tartalmazza. E körbe tartozik az időskorúak járadéka, a foglalkoztatást helyettesítő támogatás, az egészségkárosodási és gyermekfelügyeleti támogatás, az ápolási díj, az alanyi és normatív közgyógyellátás, valamint az egészségügyi szolgáltatásra való jogosultság. A rendszeres szociális segély, mint ellátási forma megszünt 2015. március 1-től. Az egyéb rendszeresen adható támogatások, mint a lakásfenntartási támogatás, az adósságkezelési szolgáltatás, méltányossági közgyógyellátás és méltányossági

${ }^{54}$ Lásd részletesen: Malakucziné Póka Mária: A Nyíregyházi járás települési szerkezeti, demográfiai, háztartási jellemzői Acta Medicinae et Sociologica Vol. 6. No. 18-19: 11-29.

${ }^{55}$ Szt. $123 . \S-126 . \S$ 
ápolási díj szabályozása megszünt azzal, hogy az előbbi kettő esetén a módosítás hatálybalépésekor már megállapított ellátásokat a módosítás hatálybalépése előtti szabályok szerint kell nyújtani. 2015. március 1-től az önkormányzatok a helyi viszonyokhoz mérten, a krízishelyzetben lévő személyek számára, illetve a helyi szociális problémák kezelésére települési támogatást nyújthatnak. A települési támogatás keretében - a korábbi rendszeres támogatások helyett - támogatás nyújtható a lakhatáshoz kapcsolódó rendszeres kiadások viseléséhez, a 18. életévét betöltött, tartósan beteg hozzátartozójának az ápolását, gondozását végző személy részére, a gyógyszerkiadások viseléséhez, a lakhatási kiadásokhoz kapcsolódó hátralékot felhalmozó személyek részére. Ugyanakkor a létfenntartást veszélyeztető rendkívüli élethelyzetbe került, valamint az időszakosan vagy tartósan létfenntartási gonddal küzdő személyek részére rendkívüli települési támogatást köteles nyújtani az önkormányzat. A támogatások egyes típusait és jogosultsági feltételeit az önkormányzat rendeletében határozza meg.

A segélyezési rendszer változtatásának hátterében az áll, hogy az egyes településeken elérhető támogatások köre eltérö, a jobb anyagi kondíciókkal rendelkező önkormányzatok többet nyújtanak, a „szegényebb” önkormányzatok területén élő rászorultak pedig kevesebb támogatást kapnak.

2015-től a segélyek finanszírozása is megváltozott, a települések eltérő mértékü állami támogatásban részesülnek figyelembe véve az egy lakosra jutó adóerő képességet.

1. ábra Kategóriák a települési önkormányzat egy lakosra jutó adóerö-képessége szerint (forint)

\begin{tabular}{|c|c|c|c|}
\hline \multirow[t]{2}{*}{ No. } & \multicolumn{2}{|c|}{$\begin{array}{c}\text { Kategóriák a települési önkormányzat egy lakosra } \\
\text { jutó adóerö- } \\
\text { képessége szerint (forint) }\end{array}$} & \multirow[t]{2}{*}{ Elismert százalék } \\
\hline & alsó határ & felső határ & \\
\hline 1. & 0 & 18000 & 100 \\
\hline 2. & 18001 & 24000 & 50 \\
\hline 3. & 24001 & 32000 & 25 \\
\hline
\end{tabular}

Forrás: 2014. évi C. törvény Magyarország 2015. évi központi költségvetéséröl

A költségvetési törvény alapján tehát azok az önkormányzatok, amelyeknek adóeröképessége meghaladja a $32.000 \mathrm{Ft}-\mathrm{t}$, nem részesülnek központi támogatásban (3200 településböl 261 település). A többi települési önkormányzat pedig differenciált mértékben jut állami támogatáshoz. A Nyíregyházi járás települései közül csak Nyíregyháza Megyei Jogú Város Önkormányzata nem részesül központi 
támogatásban. ${ }^{56}$ A további települések az alábbiak szerint jogosultak a központi finanszírozásra:

2. ábra Az önkormányzatok szociális feladatainak egyéb támogatása a központi költségvetésböl 2015-ben adóerö-képességük szerint

\begin{tabular}{|c|c|c|}
\hline $\begin{array}{c}\text { Település } \\
\text { megnevezése }\end{array}$ & $\begin{array}{l}\text { Kategória a települési önkormányzatok } 2014 \text {. } \\
\text { évi egy lakosra jutó adóerő-képessége szerint } \\
0-18000 \text { forint: a, } 18001-24000 \text { forint:b, } \\
24001-32000 \text { forint: c; } 32000 \text { forint felett: d. }\end{array}$ & $\begin{array}{l}\text { A } 2015 . \text { évi } \\
\text { támogatás } \\
\text { összege }\end{array}$ \\
\hline Apagy & $\mathrm{a}$ & 21778850 \\
\hline Kálmánháza & $\mathrm{a}$ & 11075190 \\
\hline Kótaj & $\mathrm{a}$ & 44606530 \\
\hline Nagycserkesz & $\mathrm{a}$ & 21156810 \\
\hline Napkor & $a$ & 27293710 \\
\hline Nyíregyháza & $\mathrm{d}$ & 0 \\
\hline Nyírpazony & $\mathrm{a}$ & 16798380 \\
\hline Nyírtelek & $\mathrm{a}$ & 47175120 \\
\hline Nyírtura & $\mathrm{a}$ & 8998370 \\
\hline Rakamaz & $\mathrm{a}$ & 29525150 \\
\hline Sényő & $\mathrm{a}$ & 10919150 \\
\hline Szaboles & $\mathrm{a}$ & 1789120 \\
\hline Timár & $\mathrm{c}$ & 2693010 \\
\hline Tiszanagyfalu & $\mathrm{a}$ & 16915450 \\
\hline Újfehértó & $\mathrm{a}$ & 57215050 \\
\hline
\end{tabular}

Forrás:http://www.habitat.hu/files/Onkorm_komepnzacios_keret_III_2_szocialis_feladatok _egyeb_tamogatasa_jav.pdf, Nemzetgazdasági Minisztérium: Az önkormányzatok szociális feladatainak egyéb támogatása a központi költségvetésböl 2015-ben adóerö-képességük szerint, letöltés ideje: 2015. szeptember 28.

A támogatás összege a települési támogatás finanszírozását hivatott biztosítani. Érdekes lehet annak vizsgálata, hogy a megváltozott finanszírozás hogyan befolyásolta az egyes önkormányzatok juttatásait, milyen támogatások fedezhetők az önkormányzati költségvetésből 2015-től. Mivel a települési önkormányzat határozhatja meg a támogatások formáját, feltételeit, a segítségnyújtás rendszere mára településenként eltérően alakul. A korábban nyújtott lakásfenntartási támogatás, a méltányossági alapon nyújtott ápolási díj és közgyógyellátás, valamint az adósságkezelési szolgáltatás és a temetési segély változatlan formában szinte alig elérhető a településeken. Erre alapvető magyarázat a finanszírozás, hiszen a lakásfenntartási támogatás, az adósságkezelési szolgáltatás és az ápolási díj (méltányosságból) $90 \%$-os kötött felhasználású állami támogatás és $10 \%$-os önkormányzati saját erő (lakosságszám alapú finanszírozásból megtámogatva) mellett is csak egy-egy településen volt biztosított.

\footnotetext{
${ }^{56} 2015$ átmeneti évnek tekinthető, mivel a 2014-ben megállapított támogatások, az ún. kifutó támogatások központi finanszírozása az előző év - a megállapítás évében hatályos jogszabályi rendelkezéseknek megfelelően - szabályai alapján biztosított.
} 


\begin{tabular}{|c|c|c|c|c|c|c|c|c|c|c|c|}
\hline 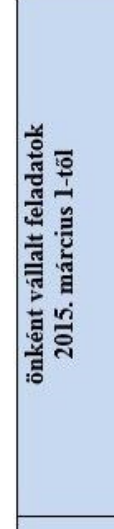 & 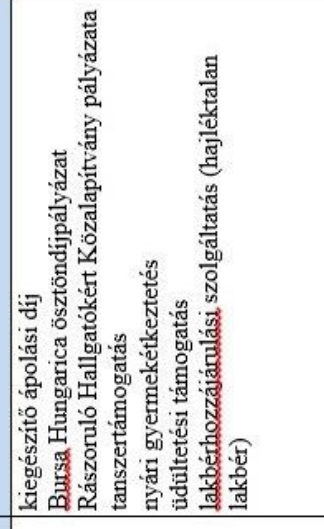 & 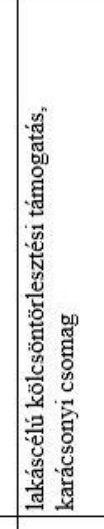 & & 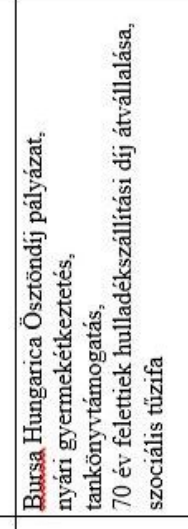 & 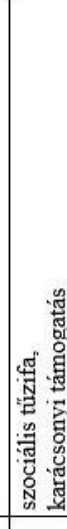 & 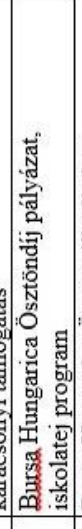 & 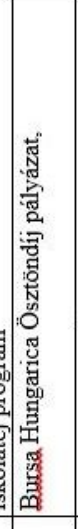 & 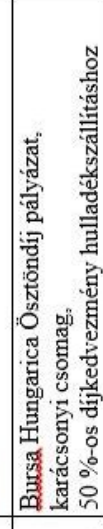 & 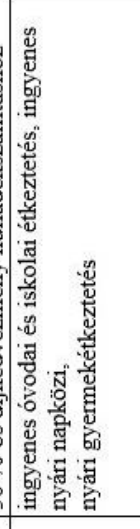 & 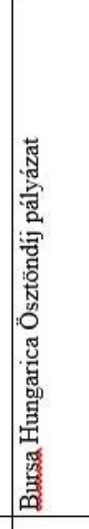 & 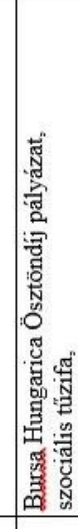 \\
\hline 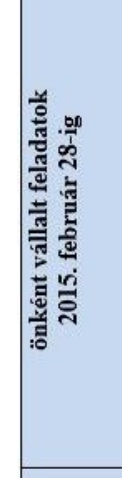 & 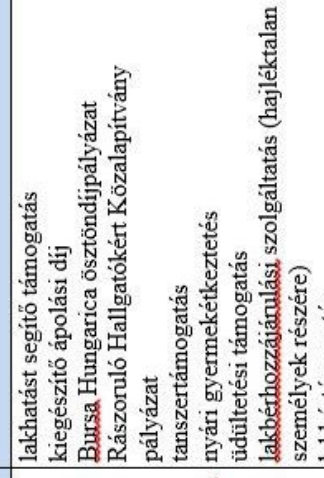 & 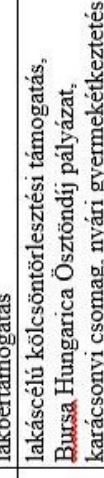 & & 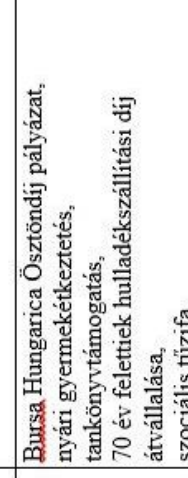 & 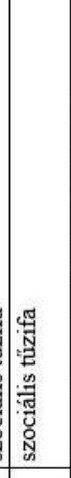 & 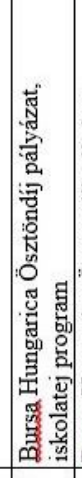 & 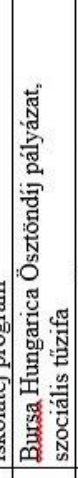 & 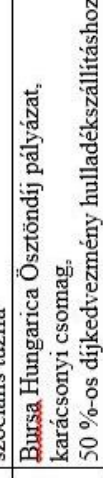 & 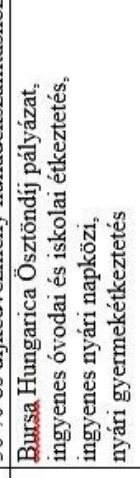 & 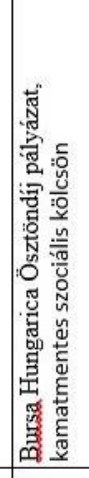 & 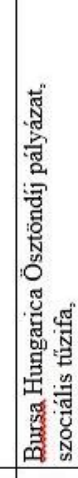 \\
\hline 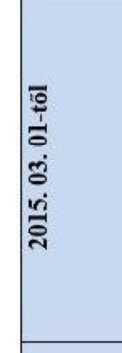 & 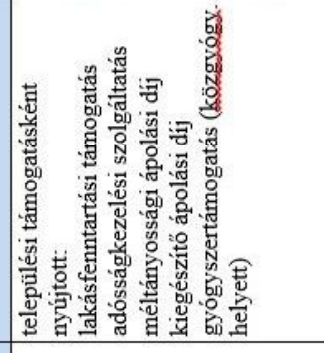 & 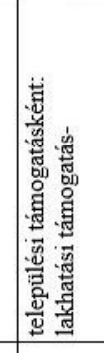 & 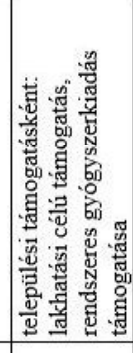 & & & & 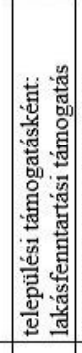 & 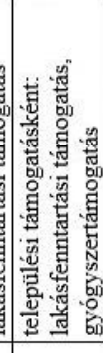 & 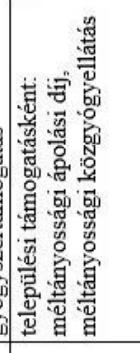 & 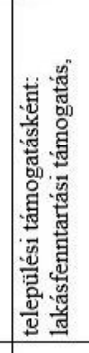 & 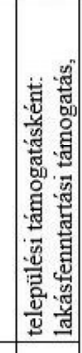 \\
\hline 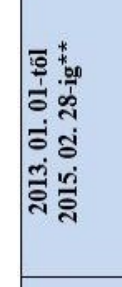 & 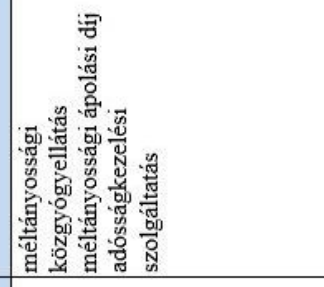 & 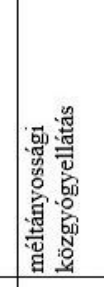 & & & & 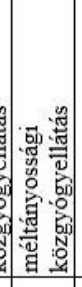 & & & & 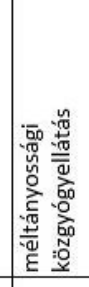 & 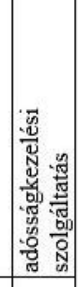 \\
\hline 青量 & $\begin{array}{l}7 \\
6\end{array}$ & $\approx$ & $\mid \begin{array}{l}\infty \\
\infty \\
\infty \\
\sigma_{0}\end{array}$ & ב̃ & 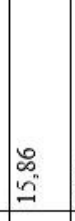 & a & $\begin{array}{l}7 \\
0 \\
0\end{array}$ & $\overrightarrow{\omega^{\prime}}$ & $\hat{n}^{2}$ & $\infty_{\infty}^{+}$ & $\frac{7}{\infty}$ \\
\hline 总 & $\stackrel{\infty}{\stackrel{\infty}{\Xi}}$ & הิ & ఏ & 年 & $\Xi$ & 㫌 & 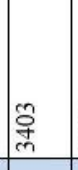 & $\begin{array}{l}0 \\
0 \\
0 \\
0\end{array}$ & $\Xi$ & $\overrightarrow{5}$ & $\exists$ \\
\hline 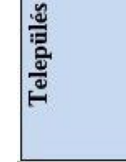 & 量 & 㟧 & औี & 范 & 要 & 尊 & 总 & 离 & 竞 & 歌 & 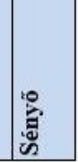 \\
\hline
\end{tabular}




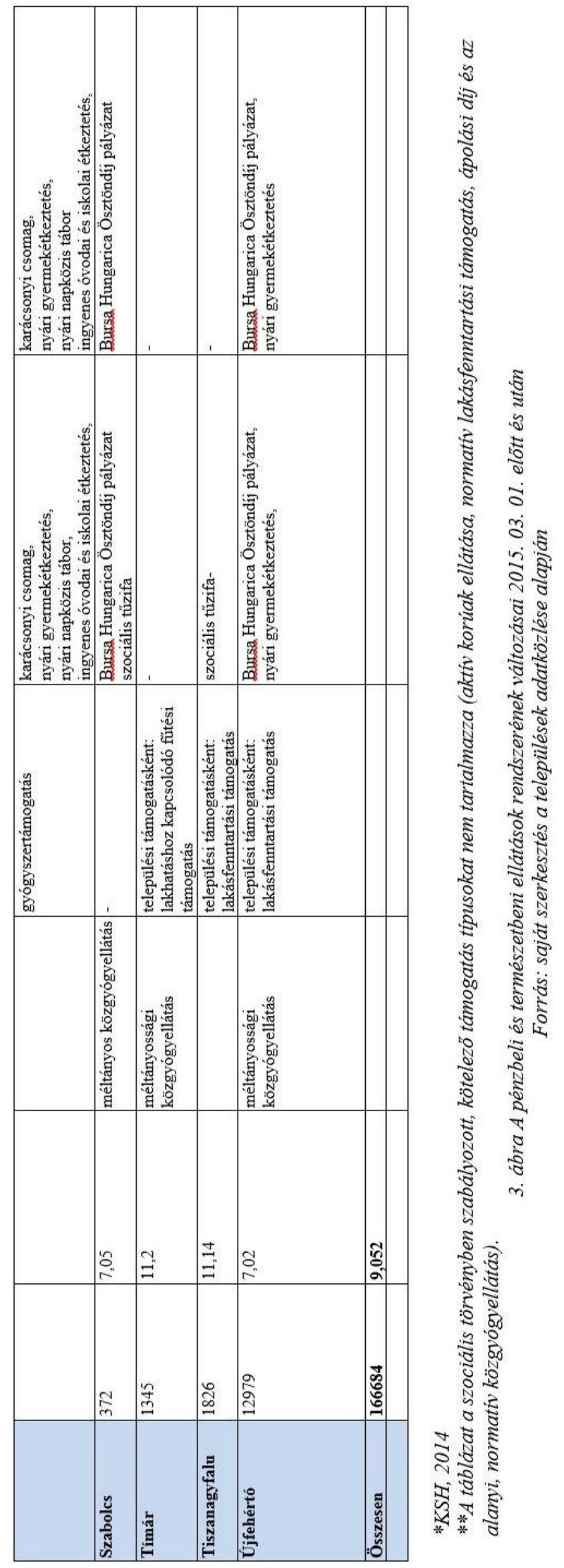


A táblázatból tehát jól látható, hogy a módosítást megelőzően a járás települései a kötelező lakásfenntartási támogatás megállapításán túl a méltányossági jogcímen megállapítható ápolási díjat, valamint közgyógyellátást jellemzően nem biztosították. A lakásfenntartási támogatás, mely ugyan 2004-től normatív támogatás, nem került a járási hivatalok hatáskörébe. Bár 2011-ig a jogszabály által is nevesített lehetőség volt a törvényben meghatározott összegen túl kiegészítő vagy helyi támogatás megállapítása, ezzel jellemzően szintén nem éltek az önkormányzatok. 2015. március 1-ét követően az önkormányzatok rendszeres pénzellátásként eltérő mértékben és módon, de leginkább a lakás fenntartásához nyújtanak támogatást. A KSH által 2013-ban vizsgált háztartások személyes kiadásaik 33,0\%-át költötték élelmiszerre, 28,8\%-ot fordítottak lakásfenntartási kiadásokra, ennek 56,6\%-át háztartási energia vásárlására. ${ }^{57}$

Adósságkezelési szolgáltatás a 40 ezer lakosságszám fölötti települések számára volt kötelező. 2015. március 1. előtt a Nyíregyházi járás területén Nyíregyházán és Sényőn müködött a szolgáltatás, jelenleg csak a megyeszékhely biztosítja lakosai számára a felhalmozódott hátralékok rendezése érdekében. Az új szabályozás során a jogosultság feltételeként elöírt jövedelemhatár nem változott, sőt, példaértékü lehet, hogy többkörös támogatást vezettek be. Ennek hátterében az áll, hogy tapasztalataik szerint egy adóssággal terhelt háztartás számára nem elegendő 1-1,5 évig támogatást nyújtani (korábban feltétel volt, hogy 24 hónapig nem volt újra igényelhető a támogatás), hanem hosszabb ideig szükséges a segítségnyújtás. A helyi rendelet alapján Nyíregyházán a helyi adósságcsökkentési támogatás mértéke nem haladhatja meg első alkalommal az adósságkezelés körébe bevont adósság 75\%-át, és összege legfeljebb kettőszázötvenezer forintot, második alkalommal az adósságkezelés körébe bevont adósság $50 \%$-át, és összege legfeljebb a százhatvanezer forintot, harmadik alkalommal az adósságkezelés körébe bevont adósság $25 \%$-át, és összege legfeljebb nyolcvanezer forintot.

2014. január 1-jétöl az átmeneti segély, a temetési segély és a rendkívüli gyermekvédelmi támogatás önálló ellátási formaként megszünt, és önkormányzati segély elnevezéssel az Szt-ben, illetve a helyi rendeletben került szabályozásra, mely elnevezése 2015. március 1-től rendkívüli települési támogatásra változott. A szociális törvény alapján a rendkívüli települési támogatás keretében a rászorulók támogatása az önkormányzatok kötelező feladata. A megvizsgált rendeletek alapján az önkormányzatok törekednek arra, hogy konkrétan meghatározzák azokat az eseteket, a törvényi elörrás figyelembe vételével, amelyek esetén segítséget nyújtanak a rászorulók számára. Valamennyi település külön nevesíti a temetéshez nyújtott támogatást és a gyógyszertámogatást, valamint lehetőséget biztosítanak méltányosság alkalmazására (rendkívüli események esetén magasabb összegủ támogatás) is. A települések többsége az alkalmanként adható összeg felső határát is meghatározza az öregségi nyugdíjminimum \%-ban.

\footnotetext{
${ }^{57}$ Létminimum, 2013; Statisztikai Tükör, 2014. június 6.
} 
Az is jól látható, hogy a települések többsége az állami források bevonása céljából kihasználja a különböző pályázati lehetőségeket (szociális tüzifa, Bursa Hungarica, nyári gyermekétkeztetés), ezzel is támogatva a helyi lakosságot.

\section{Támogató rendszerek}

A segítségre szorulók támogatása részben az állam, önkormányzat feladata, de sokszor és sok helyen hangsúlyozták már a család elsődleges szerepét. A Nyíregyházán 2008-tól folytatott életminőség szociológiai kutatást ez évben a Nyíregyházi járás területén is elvégeztük, amelynek eredményeit e tanulmánykötet taglalja. A támogató rendszerek 2008-2012-es nyíregyházi kutatásának adatai alapján egyre inkább erösödött a bizalom a mesterséges támogató rendszerek iránt. ${ }^{58} \mathrm{~A}$ segélyezés rendszerének átalakulását követően érdemes volt megvizsgálni, hogy ez a bizalom továbbra is fennálle a hivatalok és szociális szolgáltatók iránt. A vizsgálatban együtt szerepel a polgármesteri hivatal és a járási hivatal. Az adatok alapján a korábbi évekhez hasonlóan közel azonos a bizalom a hivatal és a szolgáltatók iránt egyaránt Nyíregyházán. A járási adatok szerint a kisebb településeken élök nagyobb arányban fordulnak a hivatalhoz segítségért. Tekintettel arra, hogy a járási hivatal a járásszékhelyen (Nyíregyháza) müködik, valamint további két településen müködtet a járás kirendeltséget (Rakamaz, Újfehértó), vélhetően a válaszadók az önkormányzatot jelölték meg segítséget nyújtóként. A természetes támogató rendszerek szerepét összehasonlítva mindenhol elsődleges a család szerepe, Nyíregyházán ugyanakkor egyre jelentősebb szerepet játszanak a barátok és ismerősök. Csökkent azoknak az aránya, akik nem számíthatnak segítségre, a járásban ennek az aránya fele a városinak.

\footnotetext{
${ }^{58}$ Lásd részletesen Balogh-R. Fedor, 2014, 88.
} 
4. ábra: Szociális problémájának megoldásában kinek a segitségére számithat? 2008, 2010, 2012 és 2015 (\%)

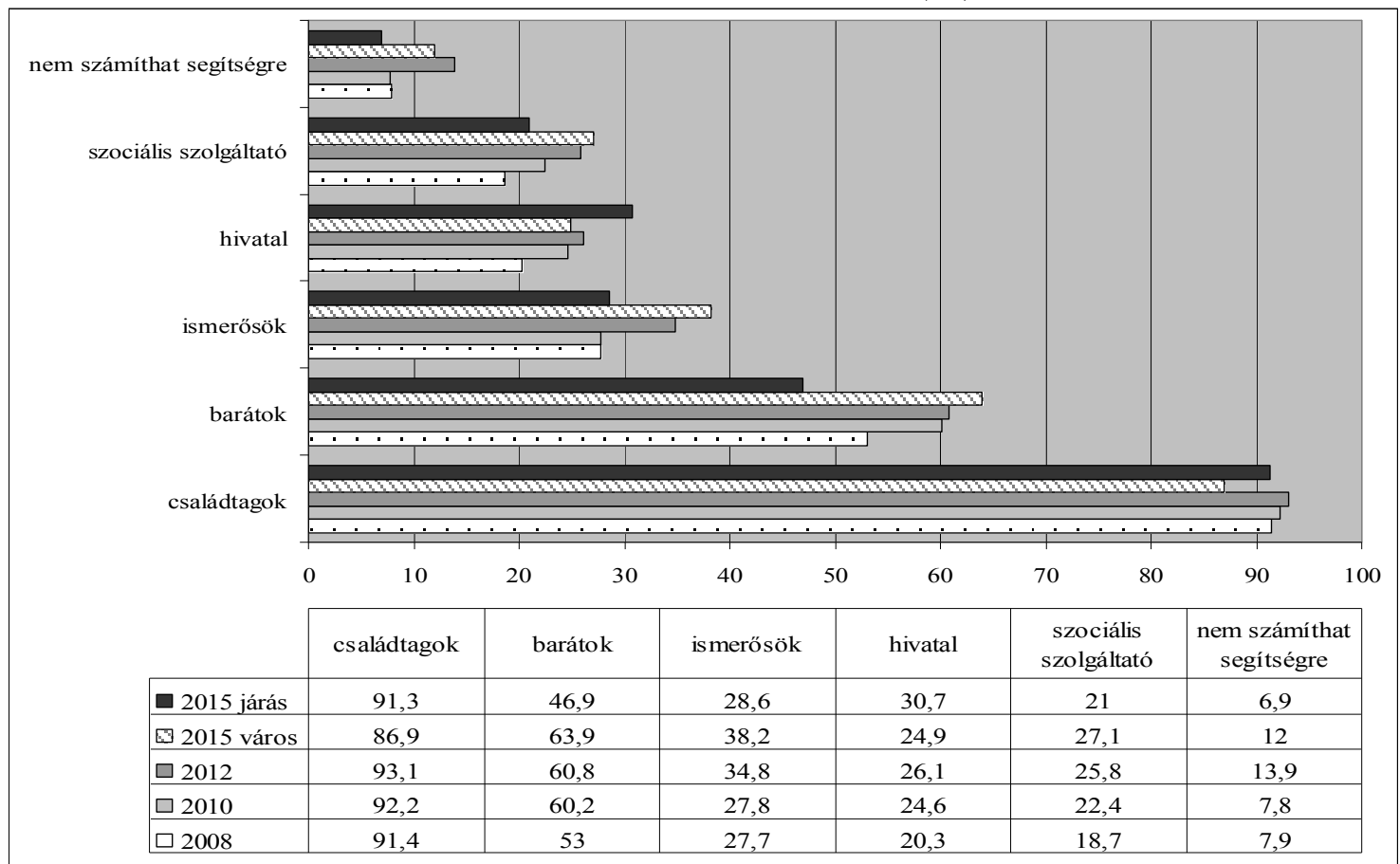

Forrás: Nyíregyháza életminősége panelkutatás, 2008, 2010, 2012 és 2015

A támogatást igénylők jellemzően az alacsonyabb iskolai végzettségüek, mind a városban, mind a járás területén. ${ }^{59}$ Ezzel szignifikáns összefüggést mutat az igénylők foglalkoztatási módja. A leggyakrabban a közmunka keretében foglalkoztatottak, az alkalmi munkával rendelkezők és a részmunkaidős alkalmazottak fordulnak segítségért az önkormányzathoz. A közmunka programot bírálók szerint láthatóan a program nem oldja meg a problémákat, hiszen az állampolgárok továbbra is segítségre szorulnak. A segélyezés rendszerének ismerői azonban tudják, hogy a vonatkozó jogszabályok szerint a segély elbírálásakor a jövedelemszámításnál figyelmen kívül kell hagyni a közfoglalkoztatásból származó havi jövedelemnek a foglalkoztatást helyettesítő támogatás összegét meghaladó részét. ${ }^{60}$ Ennek szociálpolitikai háttere éppen a segélyezési csapda elkerülése. Misetics Bálint tanulmányában olvashatjuk, hogy az európai országok milyen gyakorlatot alakítottak ki a segélyezési csapda elkerülésére. A rászorultság elbírálásakor

$59 \mathrm{Az}$ iskolázottsági szint alakulására lásd részletesen: Malakucziné Póka Mária: A Nyíregyházi járás települési szerkezeti, demográfiai, háztartási jellemzői Acta Medicinae et Sociologica Vol. 6. No. 18-19: 11-29.

${ }^{60}$ Szt. 10. § (4) bekezdés: „A jövedelemszámításnál figyelmen kívül kell hagyni

a) a kérelem benyújtását megelőzően megszünt havi rendszeres jövedelmet,

b) a vállalkozásból származó jövedelmet, feltéve, hogy a vállalkozási tevékenység megszünt,

c) a közfoglalkoztatásból származó havi jövedelemnek a foglalkoztatást helyettesítő támogatás összegét meghaladó részét." 
általában nem számítják be a munkajövedelem egy részét a jövedelembe (ezt nevezik az angol nyelvü irodalomban disregard-nak), különösen a munkába állást követő szakaszban (OECD, 2010). ${ }^{61}$ Ezt a megoldást Magyarországon az Szt. 2009. január 1-től hatályos módosításával vezették be.

5. ábra A támogatást igénylők foglalkoztatási módja, 2015 (\%)

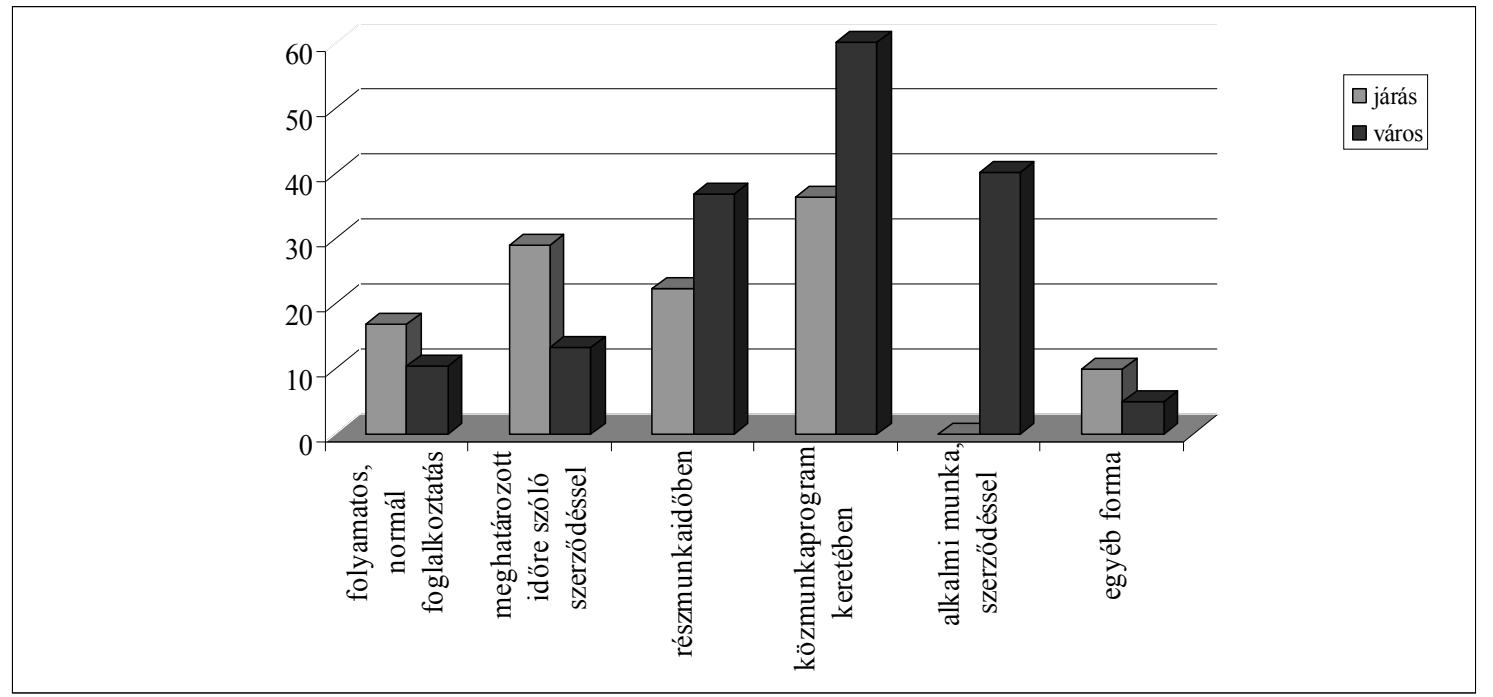

Forrás: Nyíregyháza életminősége panelkutatás, 2015

A jövedelmi viszonyok elemzésekor az látható - a fentiekkel összefüggésben -, ahogyan az egy före jutó jövedelem emelkedik, a támogatás kérelmezése egyre ritkább. Ez magától értetődő, egyértelmü lehet sokak számára, ugyanakkor téves következtetések levonásának alapja is lehet. Gondolhatnánk, hogy a rászorulók száma csökken, talán az adatok is tükrözhetik, kevesebben folyamodnak segítségért, valójában a háttérben más tényezők is állhatnak. Mind a pénzbeli és természetbeni, mind pedig a szociális szolgáltatások elsősorban a szociálisan rászorultaknak járnak, és megállapításuknál a háztartás egy före jutó jövedelmének nagysága a meghatározó. A minimálisan szükségesnek elismert jóléti szint (szegénységi küszöb) a KSH adatai alapján 2014-ben egyszemélyes háztartás esetén 67.747 Ft/hó, az egy lakosra jutó éves átlagos segélyösszeg 14036 Forint volt. Az egy lakosra jutó segélyösszeg vásárlóereje 2013-ban a 2000. évi szintet sem érte el. A szociális támogatások elértéktelenedésének egyik oka, hogy számos segély összegének megállapítási alapját képező öregségi nyugdíjminimum 2008 óta változatlanul 28500 forint. $^{62}$ Nemcsak a segély összege, hanem a kérelem elbírálásánál figyelembe vett jövedelemhatár is a nyugdíjminimumhoz kötődik, ami többségében még a szegénységi küszöb mértékét sem éri el.

Összehasonlítva a nyíregyházi és járási adatokat vidéken az alacsonyabb iskolai végzettségüek nagyobb arányban fordulnak a hivatalhoz, a városban ez alacsonyabb mértékü. Álláspontunk szerint a kisebb településeken még mindig szorosabbak a

${ }^{61}$ Misetics (2010) 3.

${ }^{62}$ Szociális segélyezés, 2013; Statisztikai Tükör, 2015. február 2. 
személyes kapcsolatok, ami kiterjed az ügyfél és ügyintéző közötti kapcsolatra is. Nyíregyháza számára is beszédes ez az adat, mert láthatóan azok maradhatnak ki a rendszerből - információ hiány, alacsony érdekérvényesítő képesség -, akik a leginkább rászorultak. Ugyanerre az álláspontra jutott Huszti Éva a társas kapcsolatok elemzésekor. ${ }^{63}$

Az információhoz való hozzájutás biztosítása alapkövetelmény, amelynek egyik lehetséges eszköze az egyre nagyobb szerepet betöltő internet. A helyi rendeleteket - többek között a pénzbeli és természetbeni ellátásokról szóló rendeletet jogszabályi ${ }^{64}$ elöírás alapján az önkormányzatoknak honlapjukon is közzé kell tenni. Arra a kérdésre, honnan értesült a segély igénybevételének lehetőségéröl, Nyíregyházán az ismerősök mellett az interneten történő információszerzést többen jelölték meg $(13,6 \%)$, mint a médiát. A járás településein mind a média, mind az Internet $(2,6 \%)$ szerepe csekély.

\section{6. ábra: Honnan értesült a segély igénybevételének lehetöségéröl?} 2008,2010, 2012, 2015 (\%)

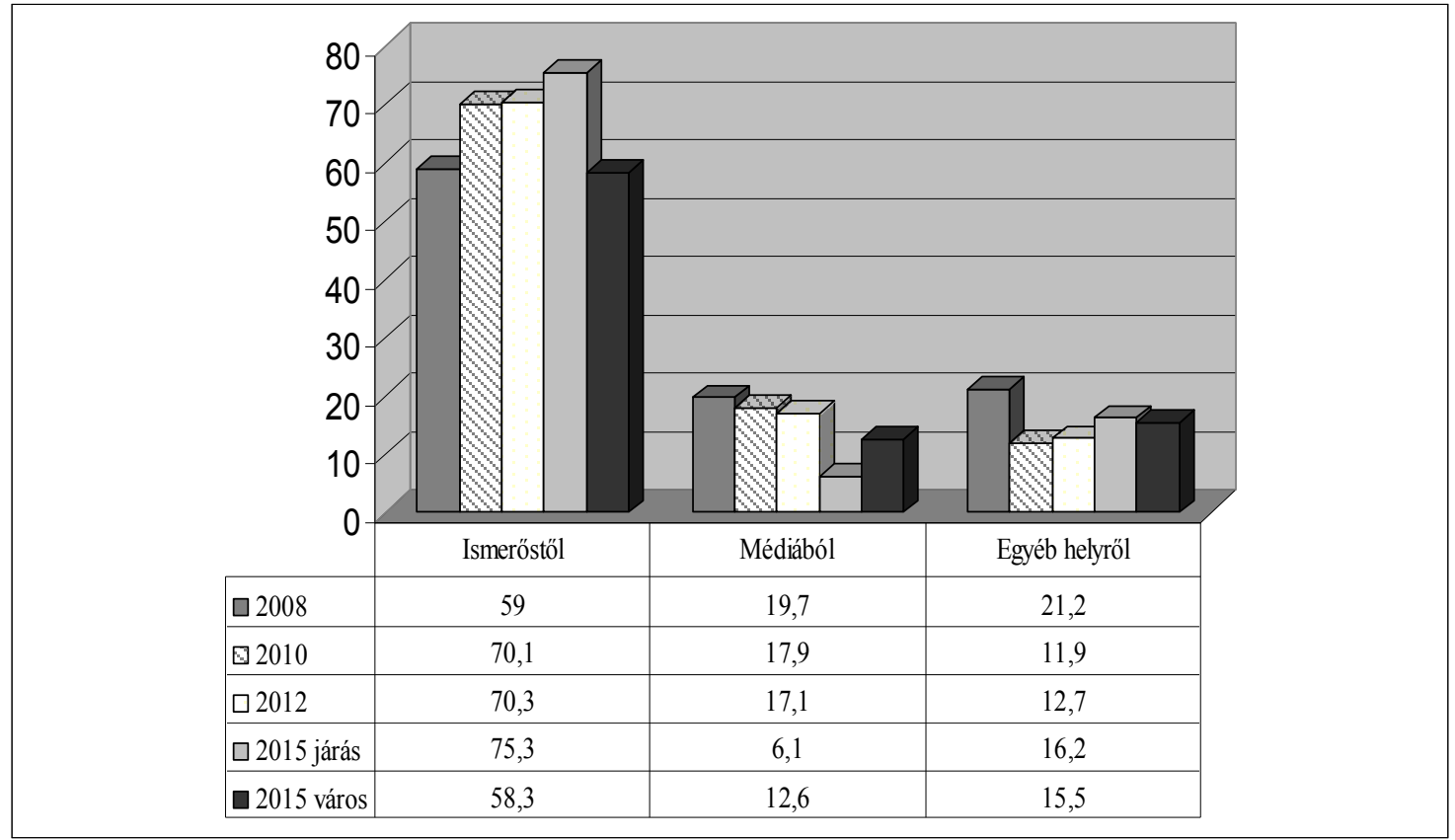

Forrás: Nyíregyháza életminösége panelkutatás, 2008,2010, 2012, 2015

Az információhoz való hozzáférést nem befolyásolja a számítógéppel való ellátottság, hiszen közel azonos arányban rendelkeznek a szükséges eszközökkel (Nyíregyháza 63,1\%, járás 60,1\%), azonban a kisebb településeken alacsonyabb az

${ }^{63}$ Lásd részletesen Huszti Éva: Mondd meg, kikkel töltöd az idődet, s megmondom, ki vagy. A társas támogatást nyújtó személyes kapcsolati háló néhány jellemzője és müködése a Nyíregyházi járásban. Acta Medicinae et Sociologica Vol. 6. No. 18-19: 121-144.

${ }^{64}$ Magyarország helyi önkormányzatairól szóló 2011. évi CLXXXIX. törvény 51. § (2) bekezdés 
Internet hozzáférés (Nyíregyháza 75,7\%, járás 57,7\%). Arra nézve nem rendelkezünk adatokkal, hogy a szolgáltatás ára vagy kiépítettsége befolyásolja-e jobban az internet használat elterjedtségét.

A Közpolitikai Kutatások Intézete felmérés-sorozatot végzett a közigazgatási reformok hatásairól is. Ez év elején megjelent tudósításokból kiderül, hogy a vizsgálat alapján a közigazgatás járási reformjáról a megkérdezett felnőtt lakosság háromnegyede hallott. A lakossági visszajelzésekből az elemzők azt a tapasztalatot is rögzítették, hogy a járások koncepcióját sokan lassabban értették meg, és a járási hivatalok által biztosított könnyebb ügyintézési lehetőség a lakosság egyes rétegeiben kevésbé tudatosult. ${ }^{65}$ A végbement változások még inkább szükségessé teszik a lakosság informálását. A járás településein dolgozó szakemberekkel készített interjúk alapján a lakosság továbbra is az önkormányzati ügyintézőkhöz fordul valamennyi segély kérelmük ügyében. Így a személyes kapcsolatoknak kiemelt jelentősége van az információk lakossághoz történő eljuttatásában.

Megoldja-e a segély a problémát? Biztosan állíthatjuk, hogy nem, csak a kezelésére szolgál.

Az ábrából jól látható, hogy a megkérdezettek szerint is legalább részben megoldást kínál a kapott támogatás. 2012. évhez képest azonban növekedett azoknak a száma, akiknek véleménye szerint teljes mértékben megoldja a problémát, és csökkent azoknak a száma, akik szerint egyáltalán nem nyújt segítséget a támogatás.

\section{7. ábra A megállapitott segély megoldotta-e problémáját? 2008, 2010, 2012, $2015(\%)$}

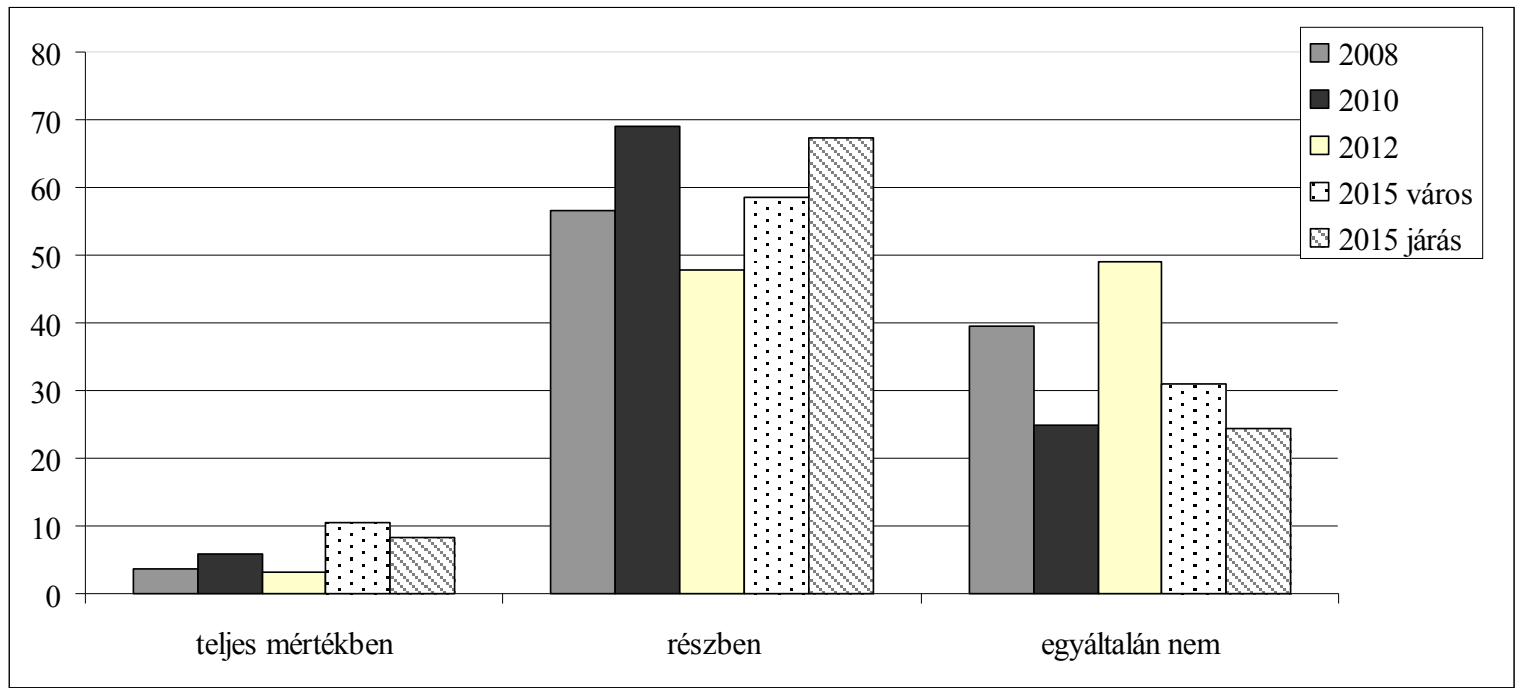

Forrás: Nyíregyháza életminősége panelkutatás, 2008, 2010, 2012, 2015

A segélyezési rendszerek vizsgálatánál szinte mindig felvetődik, hogy ki ért vele egyet, ki támogatja vagy éppen ellenkezőleg ki szüntetné meg. Az adatok alapján

65 http://www.kormanyhivatal.hu/hu/bekes/hirek/egyre-nepszerubbek-a-jarasok-alcimerdos-norbert-a-kozigazgatas-atalakitasarol, letöltés ideje: 2015. szeptember 30. 
mind a városban, mind a járásban még a jobb jövedelmüek is azt vallják, hogy a segélyezésre szükség van.

Már a 2008-2010-es kutatás során is kimutatható volt, hogy „a nyíregyháziak maximálisan elutasítják azt, hogy a segélyezés nem szükséges, azaz 'meg kellene szüntetni', vagy fel kellene számolni (ez a legelutasítottabb kijelentés), illetve egyetértenek azzal, hogy szükség van rá, mert bizonyos problémákat csak ezáltal lehet megoldani."

8. ábra „Szükséges a segélyezés” választ adók megoszlása a háztartás jövedelme szerint, 2008, 2010, 2012, 2015 (\%)

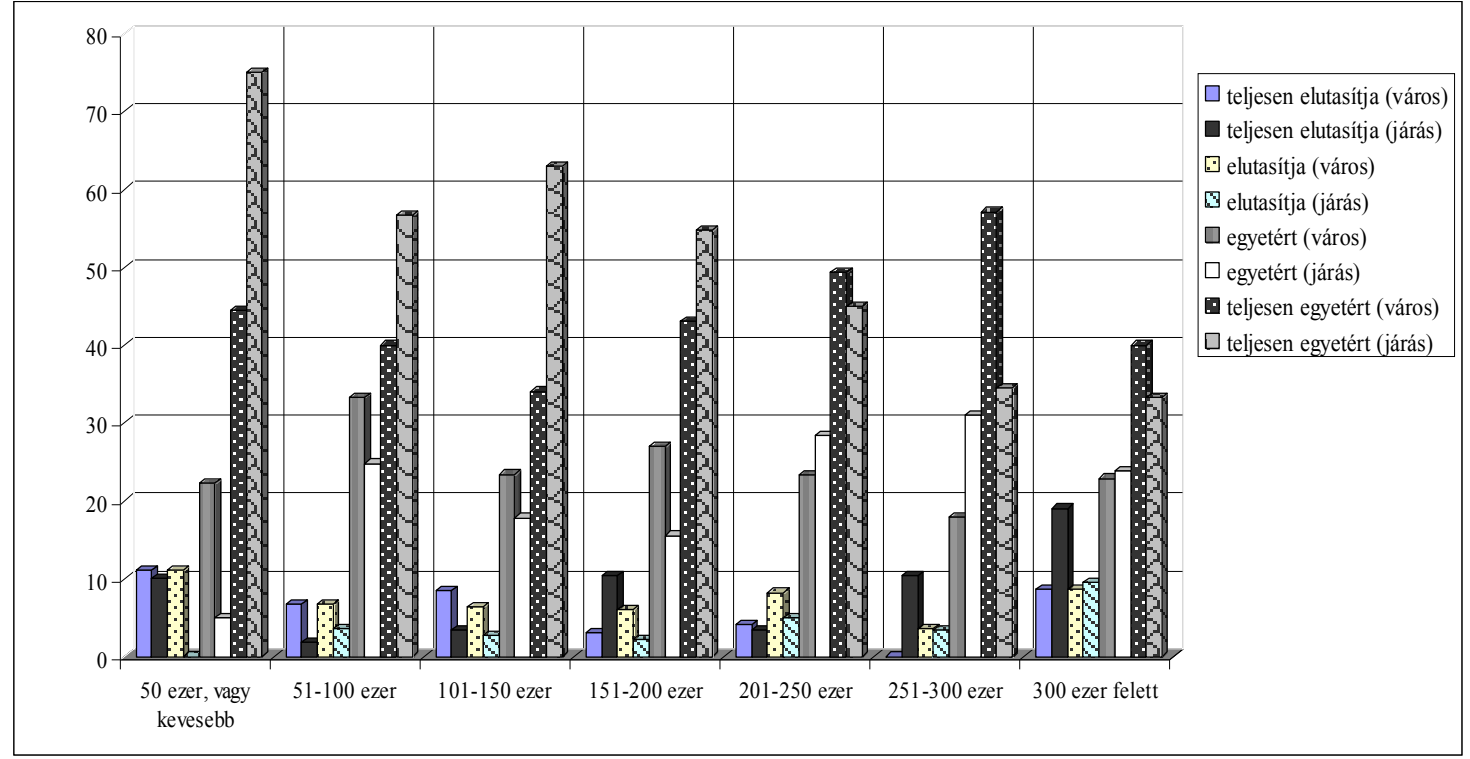

Forrás: Nyíregyháza életminősége panelkutatás, 2008, 2010, 2012, 2015

A segélyezési rendszer fenntartását a lakosságnak a háztartás jövedelmére vonatkozó értékelése is alátámasztja. ${ }^{67} \mathrm{~A}$ táblázat jól szemlélteti, hogy különösen a járás településein okoz nehézséget a megélhetés. A városi válaszadók közel felének (48,9\%), míg a járásban élők háromnegyedének (72,4 \%) jelent problémát a létfenntartás.

\footnotetext{
${ }^{66}$ Balogh-Fábián, (2012) 140.

${ }^{67}$ Lásd részletesen Fábián-Takács-Szigeti: Jövedelmi helyzet és jövedelmi szegénység Acta Medicinae et Sociologica Vol. 6. No. 18-19: 68-79.
} 


\section{9. ábra A válaszadók véleménye a háztartás havi jövedelme alapján megélhetésükröl 2015 (\%)}

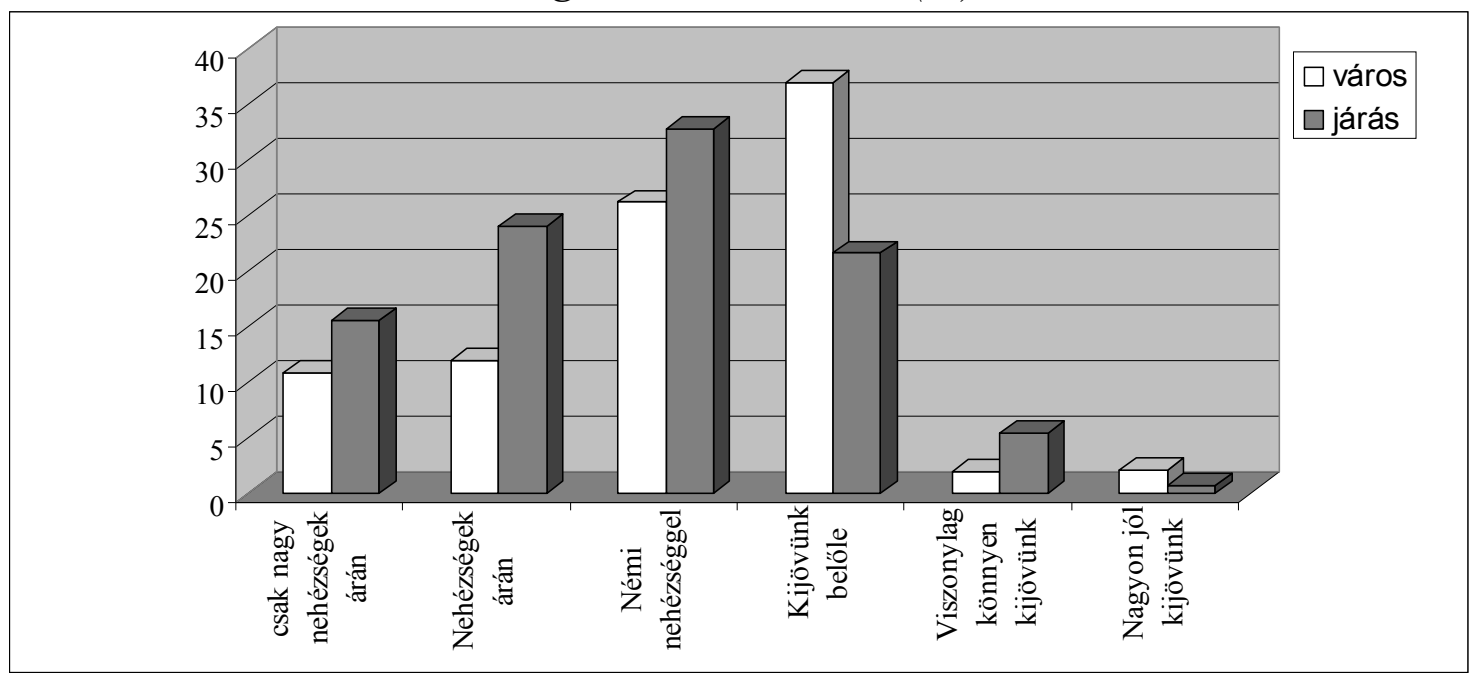

Forrás: Nyíregyháza életminősége panelkutatás, 2015

A tanulmányban nemcsak a lakosság által adott válaszokat vizsgáltuk meg, hanem a települések támogatási rendszerét és annak átalakulását. Az önkormányzati adatszolgáltatás és a helyi rendeletek tanulmányozása alapján megállapítható, hogy szinte csak szelektív ellátások érhetőek el a településeken, univerzális ellátásokkal alig találkozunk. Ez 2015. év elött is többségében igaz volt, mára már azonban a normatív támogatások megszüntetésével még inkább a településen dől el, hogy ki, milyen feltételekkel és mire jogosult. Ezek azonban a rendelkezésre álló források által meghatározottak. A kisebb települések csak az államtól kapott forrásokat használják fel, ez már eleve beszükíti a segélyezés lehetőségét.

\section{Összegzés}

A 2000-es évek elejétől elkezdődött „,visszaállamosítás”, mint folyamat, mára egy olyan vegyes szociális igazgatási rendszert hozott létre, melynek egyik szereplője a járás, a normatív, központi szabályozású támogatások elbírálására jogosult állami szerv, míg másik szereplöje a települési önkormányzatok, akik dönthetnek a diszkrecionalitást engedő segélyek szabályozásáról.

A járások számára a normatív, mérlegelést, méltányosságot nem megengedő szabályozás lehetővé teszi, hogy az ügyfelek megismerése, személyes találkozás nélkül hozzák meg döntéseiket. A kormányablakok létrehozásával mára már a döntéshozó nem találkozik a klienssel, sőt a kliensek jelentős része nem is tudja, vagy nem érti, ki hozta meg ügyében a döntést. Ugyanakkor a kutatás adatai alapján egyértelmü, hogy a kisebb települések lakói továbbra is „ügyintézőjükhöz” ragaszkodnak, segítséget tölük kérnek, panaszaikkal hozzájuk fordulnak. Az önkormányzatoktól kapott adatok alapján a szociális feladatokat ellátó ügyintézők száma sem csökkent. Felmerül a kérdés, hogy a segélyezési rendszer átalakítása, a feladatok egy részének a járásokhoz telepítése indokolt volt-e. Arra nézve jelenleg 
nincsenek adatok, hogy jelenleg mekkora létszámmal látják el a szociális hatósági feladatokat, és arra sem, hogy az új struktúra fenntartása (kormányablakok, kirendeltségek, ügysegédek utaztatása) mekkora forrást igényel. Mindeközben továbbra is a települési önkormányzatokat terheli a lakosság részéröl felmerülő szükségletek felmérése és kielégítése. A rászorulók helyzetének változása továbbra is azon múlik, hogy az önkormányzatok hogyan reagálnak a helyben jelentkező problémákra, és arra anyagi helyzetükhöz mérten milyen megoldásokat alkalmaznak. Azonban a források szükössége behatárolja lehetőségeiket.

\section{Felhasznált irodalom}

1. Balogh Erzsébet - Fábián Gyergely (2012): Támogató rendszerek, szociális problémák és segélyezés, In: Életminőség Nyíregyházán, 2008-2010. 135-153.

2. Balogh Erzsébet - R. Fedor Anita (2014): Segélyezés és támogató rendszerek In: Életminőség, Nyíregyházán, 2012, Acta Medicinae et Sociologica vol 5 No 12.13. 83-105

3. Fábián Gergely - Takács Péter - Szigeti Fruzsina: Jövedelmi helyzet és jövedelmi szegénység, Acta Medicinae et Sociologica Vol. 6. No. 18-19: 68-79.

4. Huszti Éva: Mondd meg, kikkel töltöd az idődet, s megmondom, ki vagy. A társas támogatást nyújtó személyes kapcsolati háló néhány jellemzője és müködése a Nyíregyházi járásban, Acta Medicinae et Sociologica Vol. 6. No. 18-19: 121-144.

5. Malakucziné Póka Mária: A Nyíregyházi járás települési szerkezeti, demográfiai, háztartási jellemzői, Acta Medicinae et Sociologica Vol. 6. No. 18-19: 11-29.

6. Misetics Bálint (2010) Egy radikális társadalompolitikai reformgondolat: Esély, 2010/5 3-8.

7. Mózer Péter - Tausz Katalin - Varga Attila: A segélyezési rendszer változásai. Esély, 2015/3. 43-64.

\section{Internetes hivatkozások}

- http://www.habitat.hu/files/Onkormanyzati_lakhatasi_tamogatasok_Habitat_0720.pdf

Kováts Bence: Önkormányzati hatáskörbe került lakhatási támogatások vizsgálata 31 önkormányzat példáján, letöltés ideje: 2015. szeptember 28.

- http://www.habitat.hu/files/adossagkezeles_habitat_20150224_2.pdf Gondolatok az adósságkezelési szolgáltatás megszüntetésével kapcsolatban. Összeállította: Kováts Bence, letöltés ideje: 2015. szeptember 28.

- http://www.habitat.hu/files/Onkorm_komepnzacios_keret_III_2_szocialis_feladatok_egyeb t-amogatasa_jav.pdf, Nemzetgazdasági Minisztérium: Az önkormányzatok szociális feladatainak egyéb támogatása a központi költségvetésből 2015-ben adóerő-képességük szerint, letöltés ideje: 2015. szeptember 28.

- $\quad$ http://www.kormanyhivatal.hu/hu/bekes/hirek/egyre-nepszerubbek-a-jarasok-alcim-erdosnorbert-a-kozigazgatas-atalakitasarol letöltés ideje: 2015. szeptember 30. 


\title{
Felhasznált statisztikai kiadványok
}

1. Létminimum, 2013; Statisztikai Tükör, 2014. június 6.

2. Szociális segélyezés, 2013; Statisztikai Tükör, 2015. február 2.

\section{Hivatkozott jogszabályok}

- 1993. évi III. törvény a szociális igazgatásról és szociális ellátásokról

- 2011. évi CLXXXIX. törvény Magyarország helyi önkormányzatairól

- 2014. évi XCIX. törvény Magyarország 2015. évi központi költségvetésének megalapozásáról

- 2014. évi C. törvény Magyarország 2015. évi központi költségvetéséröl

\author{
A szerző \\ Dr. Krizsai Anita Ph.D. jogász, osztályvezető \\ Nyíregyháza Megyei Jogú Város Polgármesteri Hivatal 4400 Nyíregyháza, Kossuth \\ tér 1. \\ Tóthné Csatlós Ildikó szociálpolitikus \\ Nyíregyháza Megyei Jogú Város Polgármesteri Hivatal 4400 Nyíregyháza, Kossuth \\ tér 1 .
}

